Historia Slavorum Occidentis

2021, nr 3 (30)

ISSN 2084-1213

DOI: $10.15804 /$ hso210311

Karol ModZelewski (WarsZaWA)

\title{
Przełom antypozytywistyczny i strukturalizm w Mitologii Stowian Aleksandra Gieysztora
}

Słowa kluczowe: wczesnośredniowieczna Słowiańszczyzna, religia Słowian, mitologia Słowian, Piastowie, dziejopisarstwo wczesnośredniowieczne, Aleksander Gieysztor (19161999)

Keywords: early medieval Slavs, religion of the Slavs, mythology of the Slavs, Piasts, early medieval chronicle writing, Aleksander Gieysztor (1916-1999)

Abstract: The first part of the article is devoted to a discussion of Aleksander Gieysztor's research on the religion and mythology of the Slavs. It discusses the sources of his inspiration (among others the works of Georges Dumézil on the original beliefs and mythology of the Indo-European peoples, the Romans and the Germans; the Parisian 'Annales' school) and the achieved results, e.g., the reconstruction of the pantheon of the original Slavic deities. In the second part of the paper, the author reinterprets Gallus Anonymous' account of the founding of the Piast dynasty.

W drugiej połowie lat pięćdziesiątych XX w., gdy wraz z polityczną odwilżą pojawiła się szczelina w „żelaznej kurtynie”, polska humanistyka rozpoczęła swój powrót do Europy. Po latach rozłamu europejskiej kultury, spowodowanego najpierw drugą wojną światową, a następnie izolacją od świata i stalinowskim bezruchem umysłowym, jaki Moskwa narzuciła swoim satelitom, Europa stawiała pierwsze kroki na drodze odbudowy kulturalnej jedności. W nawiązywaniu przerwanych więzi istotną rolę odegrało spotkanie i wzajemne oddziaływanie dwóch środowisk: francuskich historyków skupionych wokół paryskiego czasopisma „Annales”, którego duchowymi liderami byli wówczas Fernand Braudel (1902-1985) i Jacques Le Goff (1924-2014) oraz warszawskiej szkoły historycznej, w której czołowymi partnera- 
mi francuskich Annalistów byli wtedy Aleksander Gieysztor (1916-1999) i Witold Kula (1916-1988).

W latach 1956-1968 Polska była, na tle innych krajów „realnego socjalizmu”, oazą względnej swobody twórczej, a ustawowo zagwarantowana autonomia wyższych uczelni czyniła z polskich uniwersytetów enklawę wolnej myśli badawczej i nauczania w autorytarnym krajobrazie PRL. Środowisko „Annales”, w zgodzie z duchem czasu panującym wtedy we francuskich elitach intelektualnych, było otwarte na inspiracje ze strony marksizmu, ale nie akceptowało panującej na sowieckim lub zsowietyzowanym obszarze doktrynalnej ortodoksji. Polska historiografia - stawiająca opór marksistowskiej indoktrynacji lub skłonna do rewizji marksizmu - była więc dla Annalistów partnerem pierwszego wyboru na europejskim Wschodzie. Ze swej strony czołówka polskich historyków widziała we francuskich partnerach najbardziej nowatorski nurt europejskiej humanistyki. W kręgu „Annales” przywiązywano wielką wagę do badań nad mentalnością jako determinantą procesów historycznych. W kręgu „szkoły warszawskiej” podobało się to nadzwyczajnie, tym bardziej że sprzyjało odrzuceniu doktrynalnych dogmatów o „bazie” i „nadbudowie”. Zamiast dopatrywać się w kulturze odzwierciedlenia „stosunków produkcji”, polscy historycy skłonni byli raczej poszukiwać kulturowych uwarunkowań życia gospodarczego dawnych czasów. Przeprowadzona przez W. Kulę wnikliwa analiza rachunków folwarcznych w osiemnastowiecznej Polsce wydobyła na jaw zależność ówczesnych kryteriów racjonalnego gospodarowania od właściwych tamtej epoce preferencji ekonomicznych, czyli od hierarchii wartości. Prace W. Kuli - Teoria ekonomiczna ustroju feudalnego ${ }^{1}$ oraz Problemy i metody historii gospodarczej ${ }^{2}$, a następnie Miary i ludzie $e^{3}$ zostały niezwłocznie przetłumaczone na język francuski ${ }^{4} \mathrm{i}$ włoski ${ }^{5}$, i zyska-

\footnotetext{
1 W. Kula, Teoria ekonomiczna ustroju feudalnego: próba modelu, Warszawa 1962.

2 Tenże, Problemy i metody historii gospodarczej, Warszawa 1963.

3 Tenże, Miary i ludzie, Warszawa 1970.

4 Tenże, Théorie économique du système féodal: pour un modèle de l'économie polonaise $16^{e}-18^{e}$ siècles, trad. du polonais; édition revue et augmentée, préface de F. Braudel. Paris-La Haye 1970; tenże, Les mesures et les hommes, trad. J. Ritt; texte révu et établi par K. Pomian et J. Revel, Paris 1984 (przyp. red.).

5 Tenże, Teoria economica del sistema feudale: proposta di un modello, trad. B. Bravo e K. Żaboklicki, Torino 1970; tenże, Problemi e metodi di storia economica, trad. A. Zieliński, Milano 1972; tenże, Le misure e gli uomini dall'antichità a oggi, trad. A. Vivanti Salmon, Roma-Bari 1987 (przyp. red.).
} 
ły ogromne międzynarodowe uznanie ${ }^{6}$. Wielkie uznanie i zainteresowanie budzily też - przedstawiane wtedy nie w książkowej, lecz w eseistycznej formie - referaty Aleksandra Gieysztora wygłaszane na licznych międzynarodowych konferencjach, zwłaszcza we włoskim Centro italiano di Studi sull’alto medioevo w Spoleto.

Oddziaływanie między Annalistami i „,szkołą warszawską” było więc od początku obustronne. Wkrótce wnieśli swój wkład do tej wymiany wpływów uczniowie wspomnianych mistrzów. Wielki sukces Litości i szubienicy ${ }^{7}$ wśród zachodnich historyków i dużej rzeszy czytelników uczynił z Bronisława Geremka europejską znakomitość na długo przedtem, nim wydarzenia współczesnej historii uczyniły z niego znakomitość polityczną Unii Europejskiej.

W kręgu „Annales” od czasów Marca Blocha (1886-1944) i Luciena Febvre’a (1878-1956) - czyli od początku - uprawiano historiografię antropologizującą, badania interdyscyplinarne i komparatystykę. Nic dziwnego, że Antropologia strukturalna Claude’a Lévi-Straussa ${ }^{8}$ (1908-2009) została tam przyjęta entuzjastycznie. $\mathrm{W}$ polskiej historiografii recepcja strukturalizmu następowała w znacznej mierze pod wpływem Annalistów i - podobnie jak w całej europejskiej i światowej humanistyce - stała się dopełnieniem antypozytywistycznego przełomu.

Istotnym elementem owego przełomu był rozbrat $\mathrm{z}$ kluczową $\mathrm{w}$ pozytywistycznej historiozofii linearną koncepcją czasu historycznego. W swojej książce Porzadek czasu Krzysztof Pomian zauważył wnikliwie, że takie rozumienie czasu historii - liniowego, kumulacyjnego, nieodwracalnego - łączyło się implicite lub nawet

6 Zob. także: tenże, An economic theory of the feudal system: towards a model of the Polish economy 1500-1800, transl. by L. Garner, London 1976; tenże, Measures and men, transl. by R. Szreter, Princeton 1986; tenże, The problems and methods of economic history, transl. by R. Szreter; edited, with an introduction by S. Szreter, Aldershot 2001; tenże, Teoria econòmica del sistema feudal, trad. di G. Calaforra, València 2009 (przyp. red.).

7 B. Geremek, Litość i szubienica: dzieje nędzy i miłosierdzia, Warszawa 1989. Warto zwrócić uwagę, że obcojęzyczne wersje owego dzieła ukazaly się jeszcze przed wydaniem polskim: tenże, La pietà e la forca: storia della miseria e della carità in Europa, trad. A. Marx Vannini con la collab. di M. Frau e B. Verdiani, Roma-Bari 1986; tenże, La potence ou la pitié: l'Europe et les pauvres, du Moyen âge à nos jours, trad. J. Arnold-Moricet, Paris 1987; tenże, Geschichte der Armut: Elend und Barmherzigkeit in Europa, aus dem Polnischen von F. Griese, München-Zürich 1988; lub jednocześnie z nim: tenże, La piedad y la horca. Historia de la miseria y de la caridad en Europa, trad. J.A. Matesanz, Madrid 1989 (przyp. red.).

8 C. Lévi-Strauss, Anthropologie structurale, Paris 1958 (wyd. 1). Thumaczenie polskie: Antropologia strukturalna, wstępem poprzedził B. Suchodolski, przeł. oraz Stownik pojęć antropologii strukturalnej, oprac. K. Pomian, Warszawa 1970 (wyd. 1) (przyp. red.). 
explicite z eurocentrycznym poglądem na świat i jego ewolucję?. Wśród historyków pierwszym bodaj kontestatorem linearnego rozumienia czasu historii był Fernand Braudel - najpierw w swej pomnikowej pracy o dziejach Morza Śródziemnego ${ }^{10}$, a potem w głośnym eseju o „długim trwaniu” ${ }^{11}$. Niedawno aktualność tej kontestacji potwierdził uczeń Braudela, Maurice Aymard ${ }^{12}$. Zanim jednak do rozprawy z ewolucjonistycznym rozumieniem czasu przystąpili historycy, wypowiedział się w sprawie długiego trwania struktur opornych na zmianę C. Lévi-Strauss. W eseju Rozdwojenie przedstawienia w sztukach Azji i Ameryki pisał:

Jak wytłumaczyć występowanie tak mało naturalnej metody w kulturach oddzielonych od siebie zarówno przez czas, jak i przez przestrzeń? [...] Dlaczego pewna cecha kulturowa [...] w ciągu długiego okresu historycznego utrzymała się w stanie niezmienionym? Stabilność jest przecież nie mniej tajemnicza niż zmiana [...]. Jak to się stało, że ten sam wzór zostal przechowany przez kultury, które pod innymi względami ewoluowały w odmiennych kierunkach? Związki zewnętrzne mogą wytłumaczyć zapożyczenie, ale tylko wewnętrzne powiązania są zdolne do wytłumaczenia trwania ${ }^{13}$.

Z punktu widzenia ewolucjonistycznej historiografii było to rozumowanie niedopuszczalne. Metodologicznymi kanonami pozytywizmu były rygorystyczny wymóg synchronii i opór przeciwko argumentacji komparatystycznej („comparaison n’est pas raison”), czyli coś na podobieństwo obowiązującej w antycznym teatrze zasady jedności czasu i miejsca. Niektórzy ewolucjoniści dopuszczali wprawdzie możliwość wnioskowania na podstawie sytuacji w regionach „zapóźnionych w rozwoju” o wcześniejszych pod względem rozwoju społecznego lub kulturowego, lecz gorzej

9 K. Pomian, Porządek czasu, z jęz. francuskiego przeł. T. Stróżyński, Gdańsk 2014, s. 78, 92, 94, 99-103 (wydanie oryg.: L'ordre du temps, Paris 1984) (przyp. red.).

10 F. Braudel, La Méditerranée et le monde méditerranéen à l'époque de Philippe II, Paris 1949; wyd. polskie: Morze Śródziemne i świat śródziemnomorski w epoce Filipa II, z jęz. francuskiego przeł. T. Mrówczyński i M. Ochab, t. 1-2, Gdańsk 1976 (wyd. 1) (przyp. red.).

11 F. Braudel, Histoire et sciences sociales. La longue durée, Annales ESC 13 (1968), nr 4, s. $725-753$.

12 M. Aymard, La longue durée aujourd'hui: bilan d'un demi-siècle (1958-2008), [w:] From Florence to Mediterranean and Beyond: Essays in Honour of Anthony Molho, red. A. Molho i in., Firenze 2009, t. 2, s. 559-579.

13 C. Lévi-Strauss, Le dédoublement de la représentation dans les arts de l'Asie et de l'Amérique, Renaissance. Revue trimestrielle publiée par l'École Libre des Hautes Études de New York, 2-3 (1944-1945), s. 168-186, przedruk jako rozdział XIII w: tegoż, Antropologia strukturalna, tu: s. 344 . 
źródłowo udokumentowanych stosunkach występujących na obszarach cywilizacyjnie bardziej zaawansowanych. W polskiej historiografii tak właśnie, jako rezerwat archaicznego ładu, traktował późnośredniowieczne Mazowsze Kazimierz Tymieniecki (1887-1968) ${ }^{14}$, Henryk Łowmiański (1898-1984) zaś - ziemie litewsko-ruskie wczesnonowożytnej Rzeczypospolitej ${ }^{15}$. Ewolucjoniści byli jednak przekonani, że opóźnienia rozwojowe terenów „zacofanych” w niczym nie zmieniają powszechnego schematu rozwoju ludzkości - tyle że rozmaite obszary kroczą wolniej lub szybciej w tym samym kierunku.

W Polsce pod istotnym wpływem strukturalizmu pozostają uczniowie Mariana Małowista (1909-1988) badający historię społeczeństw pozaeuropejskich. Inspiracja ta jest widoczna zwłaszcza w pracach Michała Tymowskiego o strukturach segmentarnych, plemionach i państwach przedkolonialnej Afryki ${ }^{16}$. Nic dziwnego: przedmiot badań i osobowość mistrza uodporniły naszych afrykanistów na pokusę europocentryzmu i zbliżyły ich do antropologów.

Wreszcie za strukturalistów uznać trzeba bez wątpliwości polskich badaczy pogańskiej mitologii: Jacka Banaszkiewicza, Leszka Pawła Słupeckiego, przede wszystkim zaś samego Aleksandra Gieysztora. Inspirująca pod tym względem była dla nich zarówno wymiana myśli ze środowiskiem „Annales”, jak i wpływ wielkiego samotnika - Georgesa Dumézila (1898-1986) - który w porównawczych badaniach nad mitologią ludów indoeuropejskich wypracował własny wariant strukturalizmu i komparatystyki.

14 K. Tymieniecki, Procesy twórcze formowania się społeczeństwa polskiego $w$ wiekach średnich, Warszawa 1921; tenże, Wolność kmieca na Mazowszu w XV w., Poznań 1921; tenże, Sądownictwo w sprawach kmiecych a ustalanie się stanów na Mazowszu pod koniec wieków średnich, Poznań 1922; tenże, Prawo niemieckie w rozwoju społecznym wsi polskiej, Kwart. Hist. 37 (1923), s. 38-78; tenże, Początki spoteczeństwa i państwa litewskiego, Roczniki Dziejów społecznych i gospodarczych 2 (1932-1933), s. 145-162 (przyp. red.).

15 Np. H. Łowmiański, Studia nad początkami społeczeństwa i państwa litewskiego, t. 1-2, Wilno 1931-1932; tenże, Studia nad dziejami Wielkiego Księstwa Litewskiego, Poznań 1983; tenże, Studia nad dziejami Stowiańszczyzny, Polski i Rusi w wiekach średnich, Poznań 1986. Należy dodać, że dwie ostatnie prace, wydane u schyłku życia, w zasadniczym swym zrębie powstały kilkadziesiąt lat wcześniej - w czasie gdy ich autor piastował na Uniwersytecie Wileńskim Katedrę Historii Europy Wschodniej (1933-1939) (przyp. red.).

16 M. Tymowski, Państwa Afryki przedkolonialnej, Wrocław 1999; tenże, The origins and structures of political institutions in pre-colonial Black Africa: dynastic monarchy, taxes and tributes, war and slavery, kinship and territory, with a foreword by H.J.M. Claessen, Lewistone 2009. 
Mitologia Stowian A. Gieysztora została opublikowana po raz pierwszy w roku 1982 nakładem Wydawnictw Artystycznych i Filmowych w ramach popularnej serii „Mitologie świata”. Stutysięczny nakład rozszedł się bardzo szybko i już w 1986 r. ukazało się wznowienie - również szybko wyczerpane, mimo że nie była to łatwa lektura; należy dodać, że wydawca wymógł na autorze rezygnację z opatrzenia tekstu książki przypisami. W latach dziewięćdziesiątych Gieysztor przygotowywał edycję niemiecką z aparatem naukowym, ale ciężka choroba i śmierć nie pozwoliły mu zrealizować tego zamiaru. Nowe wydanie, opracowane i opatrzone przypisami na podstawie rękopiśmiennych notatek Autora, czynionych z myślą o niemieckiej edycji, jest wielką zasługą Anety Pieniądz. Ukazało się ono w 2006 r.

W uwagach wstępnych do tej książki A. Gieysztor pisał:

Wydaje się, że najwięcej poznano z zamierzchłych śladów wierzeniowych Słowian dzięki nowym metodom semiotyczno-strukturalistycznym stosowanym na pograniczu folkloru i językoznawstwa. Po tym, co zawdzięczamy Dumézilowi - twórcy odnowienia wiedzy o zachowaniach sakralnych ludów indoeuropejskich - $\mathrm{i}$ jego szkole myślenia i studiów, nie sposób trwać przy dawnym, jeszcze pozytywistycznym opisie uratowanych szczątków rozbitej całości, badanych metodą prawie tylko filologiczną. [...] Dzięki innym badaczom, zwłaszcza etnografom, przedstawicielom antropologii kulturowej i semiotyki, doceniamy religioznawczy walor kultury ludowej, która także już wchodzi do warsztatu historyka religii [...] Folklor zdumiewa prawdziwie długim trwaniem mitów ukrytych w obrzędach, bajkach, przysłowiach, a czasem [...] w epice ludowej. Nie ma wątpliwości, że tu właśnie tkwią jeszcze niewykorzystane w pełni możliwości poznania słowiańskich wierzeń i praktyk religijnych. Ich dokumentację pisaną zawrzeć można w jednym tomie tekstów i trudno spodziewać się ich przyrostu [...]. W nadziejach na wzbogacenie naszego plonu badawczego góruje dziś kultura ludowa, ów do dziś żywy, a w każdym razie niezbyt dawno uchwycony przez naukę relikt świadomości społecznej. [...] Kultura tradycyjna jest źródłem historycznym służącym do odtworzenia stanu starszego, który można nazwać pierwszym progiem chrystianizacji, a więc stanu ze schyłku wczesnego średniowiecza $^{17}$.

Nieskłonny zazwyczaj do powtórzeń, Gieysztor w swej ostatniej książce raz jeszcze powraca do tego wątku:

17 A. Gieysztor, Mitologia Stowian, Warszawa 1982, s. 27-29. 
Alternatywa wysuwana w polemice z Dumézilem i jego szkołą to postawa krytyczno-pozytywistyczna, nakazująca badanie religii ludów indoeuropejskich każdej z osobna jako systemów niepowiązanych ze sobą lub wykazujących tylko najogólniejsze analogie. Alternatywą [wobec Dumézilowskiej neokomparatystyki - K.M.] jest także akceptacja milczenia tekstów, a stąd przyjmowanie bardzo późnego pojawiania się form politeistycznych poza obszarem śródziemnomorskim i indoirańskim [...]. Neokomparatystyka religioznawcza [...] bada zaś systemy wierzeń indoeuropejskich w przekonaniu o ich genetycznym związku. Sprowadza posiłki zaczerpnięte z pól bogatszych na rzecz obszarów uboższych, próbując do swych zamierzeń wykorzystać wiele nauk o człowieku. Stawia sobie cele wyjaśniające, nie kontentując się fragmentarycznym opisem ${ }^{18}$.

Cytuję ową mantrę z prawdziwą przyjemnością. Z punktu widzenia pozytywistycznych nakazów, a zwłaszcza zakazów, mój mistrz pisał okropne herezje. Czynił to z rozmysłem. Nie wynika stąd, by lekceważył on bezcenny wkład pozytywistów w budowę warsztatowych fundamentów naszego zawodu. Sam Gieysztor był w tej dziedzinie uznanym autorytetem i nie zmienił wysokiej oceny dorobku pozytywistycznych poprzedników. Deklarował natomiast zamiar przekroczenia znaków zakazu, którymi pozytywizm próbował zamknąć horyzont badań historycznych w ciasnym czasowo-przestrzennym kojcu.

W ostatnim zdaniu Mitologii Stowian autor podsumował wyzwanie rzucone temu ograniczeniu horyzontów badawczych: „folklor słowiański - obok wytworzenia postaci synkretycznych - zachowywał [...] prawie do dziś dnia podstawowe zręby tradycyjnego poglądu na świat i jego projekcję sakralną"19. Określając to, śladem Braudela, jako zjawisko długiego trwania, A. Gieysztor manifestował swój związek z tradycją Annalistów, i w tych kategoriach interpretował relację o kulcie pogańskim słowiańskich Rugian zapisaną przez Saksa Gramatyka w Gesta Danorum (XIV, 39).

Nie wiemy, czy sam Sakso za młodu brał udział w zwycięskiej wyprawie duńskiego króla Waldemara I na Rugię, uwieńczonej w 1168 r. zdobyciem Arkony i zniszczeniem rugijskich obiektów kultu pogańskiego. Wiemy natomiast, że w wieku dojrzałym Sakso był bliskim współpracownikiem biskupa Roskilde, późniejszego arcybiskupa Lundu Absalona, który w swoim testamencie obdarował Saksa i nazwał go „swoim klerykiem” (clericus meus). Absalon nie tylko uczestniczył w zdobyciu Arkony, ale pełnił tam u boku króla Waldemara funkcję swego rodzaju „komisarza po-

18 Tamże, s. 62.

19 Tamże, s. 294. 
litycznego" duńskiej wyprawy i osobiście kierował demonstracyjnym zniszczeniem tamtejszej świątyni i posągu Świętowita. Nadzwyczajna szczegółowość opisu tego obiektu i jego rozbiórki oraz odprawianego tam do 1168 r. kultu tłumaczy się dość prosto i bez gubienia się w ryzykownych domysłach: Sakso zapisywał w tym wypadku wspomnienia swojego pryncypała, czyli Absalona - uczestnika misji z $1168 \mathrm{r}$. i reżysera opisywanych zdarzeń. Stąd uderzający w tym opisie walor naocznego świadectwa ${ }^{20}$. Absalon zapoznał się także - oczywiście nie naocznie, ale z dobrego źródła, gdyż negocjował z rugijskimi przywódcami szczegóły dotyczące likwidacji kultu pogańskiego - z najważniejszymi obrzędami kultowymi pogan. Stąd znalazła się w kronice Saksa szczegółowa relacja o wielkiej uroczystości odprawianej w Arkonie po zbiorach, przed odsłoniętym na tę okazję posągiem Świętowita. W kulminacyjnym momencie obrzędu, gdy kapłan stał obrócony plecami do idola, a twarzą do zebranego przed świątynią tłumu, przynoszono okrągły kołacz, dorównujący prawie wielkością wzrostowi człowieka. Kapłan stawiał ów kołacz przed sobą (czyli między sobą a ludem) i pytał zgromadzonych Rugian, czy jego - tj. kapłana - widzą. Tłum odpowiadał twierdząco, na co kapłan życzył zebranym, by w następnym roku wcale nie mogli go zobaczyć (quibus illi a se videri respondentibus, ne post annum ab iisdem cerni posset, obtabat). Niedomyślnym czytelnikom Sakso wyjaśnil, że było to życzenie obfitszego urodzaju w roku następnym, wskutek czego kołacz byłby jeszcze większy i całkowicie zasłonił kapłana (Quo precationis (...) futura messis incrementa poscebat) ${ }^{21}$.

Komentując ten dwunastowieczny tekst, A. Gieysztor nie zawahał się zestawić go z dziewiętnasto - i dwudziestowiecznymi zapisami etnograficznych badań nad słowiańskim folklorem. „Zarówno wśród Słowian wschodnich, jak i południowych owo paradoksalne życzenie, aby gospodarza nie było widać, powtarza się najdokładniej na Ukrainie - «spoza kołacza wielkanocnego», w Hercegowinie brzmi «spoza kołacza na Boże Narodzenie». Na Białorusi i w Bułgarii - «spoza placków w poniedziałek zaduszny»”. Dušan Třeštík powiększył ten wykaz o sprawozdanie z badań etnograficznych na Słowacji, gdzie gazda, kryjąc się za okrągłym bochnem chleba, pytał domowników, czy go widzą i życzył, by w następnym roku bochen

20 Zob. K. Malicki, Chrzest Rugii 1168 r. Model chrystianizacji - praca magisterska pod kierunkiem prof. J. Banaszkiewicza, Warszawa 2000 (maszynopis w archiwum Dziekanatu Wydziału Historii Uniwersytetu Warszawskiego).

21 Saxonis Grammatici Gesta Danorum, lib. XIV, cap. 39, wyd. J. Olrik, H. Raedr, t. I, Hauniae 1937, s. 473. 
zasłonił go całkowicie ${ }^{22}$. Obyczaj ten był, jak widać, etnograficznie uchwytny na całej Słowiańszczyźnie.

Kluczem do łącznej interpretacji tych obyczajów ludowych i kronikarskiego tekstu Saksa Gramatyka jest jednak wyszperany przez Gieysztora zapis - również etnograficzny - dialogu między popem a wiernymi w bułgarskiej wiejskiej cerkiewce. „Duchowny stawał poza stosem ofiarnym okrągłych chlebów i zapytywał głośno zebranych: «widzicie mnie»? - na co mu odpowiadano: «tak, widzimy cię, widzimy». Z kolei duchowny mówił: «obyście na przyszły rok nie mogli mnie całkiem widzieć», w nadziei, że plon będzie jeszcze obfitszy"23.

W przeciwieństwie do życzeń składanych domownikom przez gospodarza, tym razem rzecz dzieje się - podobnie jak w dwunastowiecznej Arkonie - w świątyni, dialog zaś toczy się między kapłanem a wiernymi. W dwunastowiecznej Arkonie jest to co prawda świątynia pogańska, a w dwudziestowiecznej Bułgarii - chrześcijańska, lecz role obu stron i toczony przez nie dialog są w obu wypadkach integralną częścią kultu religijnego. Wreszcie sam obrzędowy dialog jest prawie równobrzmiący, nieomal słowo w słowo. Mimo dystansu czasowego (niemal ośmiu stuleci) i dystansu przestrzennego dzielącego północno-zachodni i południowo-wschodni kraniec Słowiańszczyzny dialog ten ma niebudzące wątpliwości i całkowicie niezależne jedno od drugiego poświadczenia źródłowe. Jak to wytłumaczyć?

$\mathrm{Z}$ ortodoksyjnie pozytywistycznego punktu widzenia tłumaczyć tego nie trzeba, a nawet nie wolno, gdyż oba teksty, mimo że współbrzmiące, są z natury rzeczy nieporównywalne. Ten gest odmowny wobec źródeł nie ma jednak podstaw empirycznych; jest zwykłą projekcją dziewiętnastowiecznych aksjomatów dotyczących rozumienia historycznego czasu i kulturowej przestrzeni. Historykowi - nawet (a może zwłaszcza) pozytywiście - nie uchodzi jednak odwracać się plecami do niewygodnych źródeł. A. Gieysztor słusznie dopatrzył się w dialogu bułgarskiego popa z wiejskimi parafianami zjawiska „długiego trwania”. To dobra okazja, by przyjrzeć się bliżej tej strukturalistycznej kategorii.

Zestawienie z praktykami kultowymi odprawianymi przed posągiem Świętowita w pogańskiej Arkonie wskazuje jasno, że w bułgarskiej cerkiewce gdzieś na przełomie XIX i XX w. praktykowano - w formie powierzchownie schrystianizowanej - prastary pogański rytuał. Dla historyków Kościoła żadna w tym dziwota. Warto jednak podkreślić, że przedchrześcijański wzór kulturowy przetrwał w tym wypadku

22 D. Třeštík, Mýty kmene Čechů (7.-10. století), Praha 2003, s. 7 n.
23 A. Gieysztor, Mitologia, s. 127 n. i literatura cytowana w przyp. 280. 
osiem wieków, w czasie których mnóstwo się zmieniło: przyjęto chrzest, zbudowano państwowość, zaczęto się posługiwać wynalazkiem druku, rozpoczęto masową alfabetyzację, obejmując nią stopniowo także ludność wiejską, pojawiła się kolej i zapoczątkowana została - mimo peryferyjnego niedorozwoju - rewolucja przemysłowa. A pop do ludu wiejskiego swoje, niczym pogański kapłan przed wieloma wiekami. To dobitny przykład długiego trwania wzoru archaicznej kultury, opornego na zmiany innych struktur.

Przykład ten dodaje wiarygodności wynikom badań nad folklorem jako nośnikiem „długiego trwania” wzorów kultury tradycyjnej wywodzących się sprzed chrystianizacji. Zbieżność kronikarskiego tekstu Saksa Gramatyka z ludową obrzędowością uchwyconą przez etnografów na obszarach całej Słowiańszczyzny stanowiła w oczach Gieysztora argument na rzecz tezy o wspólnym zrębie ogólnosłowiańskiej mitologii. Uważał on bowiem, że „obrzęd i mit były dwiema nierozerwalnymi postaciami sensownej interpretacji rzeczywistości w kategoriach uświęconych norm etyki indywidualnej i współżycia społecznego, a także środkami wyrażania stosunku ludzi do przyrody"24. Wykrycie wspólnoty obrzędowej obejmującej całość słowiańskiego świata prowadziło w rezultacie - drogą porównawczej analizy źródeł pisanych, zabytków archeologicznych, folkloru i poszukiwań językoznawczych - do próby rekonstrukcji ogólnosłowiańskiego zrębu wyższej mitologii, w tym zwłaszcza wspólnego panteonu naczelnych i pomniejszych bóstw.

Porównawczy horyzont religioznawczej refleksji A. Gieysztora był zresztą szerszy od Słowiańszczyzny. Obejmował, śladem Dumézila, cały indoeuropejski obszar językowy; czerpał z mitologii indoirańskiej, bałtyjskiej, germańskiej, celtyckiej, rzymskiej. Jak słusznie zauważył Leszek P. Słupecki w erudycyjnym posłowiu do Mitologii Stowian, Gieysztor nie szukał w pracach Dumézila rozwiązań, czerpał z nich metodologiczne inspiracje. Szukał więc, niczym chemik w tablicy Mendelejewa, słowiańskich bóstw mających odpowiedniki u innych ludów indoeuropejskich. Budziło to niekiedy sceptyczne reakcje nie tylko wśród oponentów, lecz także wśród uczniów i zwolenników jego religioznawczej neokomparatystyki.

Dobrym tego przykładem jest poszukiwanie przez A. Gieysztora słowiańskiego odpowiednika boskich bliźniąt - żywicieli, dbających o zapewnienie ludziom obfitości dóbr. Punktami odniesienia są tu wedyjscy Aświnowie. Ich odpowiednikiem w mitologii rzymskiej są dioskurowie Kastor i Polluks. Tacyt - prawdziwy strukturalista avant la lettre - dostrzegł te same bóstwa w mitologii Germanów: „u Naharna- 
walów zobaczyć można gaj, miejsce starożytnego kultu, któremu przewodzi kapłan w kobiecym stroju: mówią, że bogami są tam - tłumacząc na kategorie rzymskie - Kastor i Polluks. Taki jest ich charakter, nazywają się Alci... Czczą ich jako braci i jako młodzieńców" ${ }^{25}$. Archeologicznym śladem kultu boskich bliźniąt u Słowian jest, zdaniem Gieysztora, „odkryty na Fischerinsel, wyspie położonej na jeziorze Tolensee w Meklemburgii, tej samej gdzie lokalizowano Radogoszcz, posąg drewniany wysokości $178 \mathrm{~cm}$, złożony z dwu postaci zrośniętych głowami i tułowiem, datowany warstwami kulturowymi na XI i XII wiek"26. Ze swej strony Jacek Banaszkiewicz dopatrywał się cech dioskurycznych w opisanych przez Saksa Gramatyka figurach Porewita i Porenuta w Gardźcu (właściwie Korzenicy) na Rugii ${ }^{27}$. W interpretacji bliźniaczego posągu z Fisherinsel ostrożny sceptycyzm zachował natomiast L.P. Słupecki. Jego zdaniem „równie dobrze podwójna postać tej rzeźby przedstawiać może jednego boga o dwóch głowach i być wyrazem poświadczonej w źródłach pisanych wielogłowości bóstw zachodniosłowiańskich"28.

W odniesieniu do posągu z Fisherinsel mam inne wrażenie. Wygląda on jak bracia syjamscy zrośnięci bokami, a obie twarze zwrócone są w tę samą stronę - do widza, podczas gdy znane nam wizerunki lub opisy wielogłowych bóstw zachodniosłowiańskich były zwrócone twarzami w cztery strony świata lub w dwie przeciwne strony. Ale wrażeń się nie uzasadnia i nie będę się o to spierać. Na dzieło sztuki sakralnej, jakim jest rzeźba z Fisherinsel, każdy widz może patrzeć po swojemu.

25 Tacyt, Germania, [w: ] Tacyt, Dzieła, t. 2, tłum. S. Hammer, Warszawa 1957, cap. 43; por. Publius Cornelius Tacitus, Germania, [w:] Publius Cornelius Tacitus, Agricola; Germania; Dialogus, The Loeb Classical Library. Tacitus, t. 1, Cambridge, Mass.-London 1996, s. 94: apud Naharnavallos antiquae religionis locum ostenditur. Praesidet sacerdos muliebri ornatu, sed deos interpretatione Romana Castorem Pollucemque nominant, ea vis nimini, nomen Alcis ut fratres tamen, ut iuvenes venerantur. Wątki dioskuryczne w mitologii Germanów i Celtów tropili G. Dumézil (Bogowie Germanów: szkice o kształtowaniu się religii skandynawskiej, przeł. A. Gronowska, Warszawa 2006, s. 32-35) oraz S. O’Brien (Dioscuric Elements in Celtic and Germanic Mythologies, The Journal of Indo-European Studies 10 [1982], s. 117-136).

26 A. Gieysztor, Mitologia, s. 200.

27 J. Banaszkiewicz, Pan Rugii - Rugiewit i jego towarzysze z Gardźca - Porewit $i$ Porenut. Sakso Gramatyk, Gesta Danorum, XIV, 39, 38-41, [w:] Słowiańszczyzna w Europie, wyd. Z. Kurnatowska, Wrocław 1996, t. I, s. 80-81.

28 L.P. Słupecki, Posłowie, [w:] A. Gieysztor, Mitologia Słowian, Warszawa 2006, s. 334. 
Nie godzę się natomiast z powszechnie, choć na ogól milcząco przyjmowaną opinią, jakoby istnienia bliźniaczych bóstw na Słowiańszczyznie nie potwierdzał żaden źródłowy tekst. Uważam, że jest taki tekst. W dodatku wszyscy czytaliśmy go wielokrotnie i może dlatego opatrzył się on nam tak dalece, że czytamy nie dość uważnie. To Anonim-Gall I, 1-3, czyli zapis mitu dynastycznego Piastów w najdawniejszej kronice polskiej.

Kronika powstała w dramatycznych okolicznościach po oślepieniu i śmierci Zbigniewa, gdy duchowy przywódca opozycji arcybiskup Marcin obłożył Bolesława Krzywoustego klątwą za bratobójstwo. Groziła detronizacja księcia. Bolesław III był zaś po fizycznej eliminacji brata ostatnim żyjącym przedstawicielem rodu Piastów i eksponowanie charyzmy tego rodu jako przyrodzonych panów Polski należało do najważniejszych zadań propagandowych kronikarza. Pogański mit dynastyczny miał najwidoczniej w oczach grupy rządzącej ( w tym duchownych o rodzimych korzeniach) wciąż żywą wartość integrującą. Polska nie była pod tym względem wyjątkiem.

Zakonnik, który ten mit relacjonował, był w trochę niezręcznej sytuacji. Gall wyjaśnił jednak swoim czytelnikom (a byli to z natury rzeczy ludzie piśmienni, czyli duchowni, po części obcokrajowcy), że postrzyżyny, wokół których osnuta jest akcja opowieści, były pogańskim rytuałem przejścia połączonym z nadaniem przez ojca dorastającemu chłopcu imienia. Często było to imię zapowiadające chwalebną przyszłość. Kronikarz przyznał się też do tego, że - nie chcąc rozwodzić się nad historią ludzi, których skaził błąd bałwochwalstwa - trochę ten mit ocenzurował. Ale nie próbował schrystianizować jego narracyjnej struktury.

W archaicznych kulturach nośnikiem ideowych treści mitu był fabularny wątek opowieści. W zrelacjonowanym przez Galla piastowskim micie wątek ten przedstawia się dość prosto: w Gnieźnie książę Popiel przygotowuje wystawną ucztę z okazji postrzyżyn swoich dwóch synów. W tym samym czasie na podgrodziu gnieźnieńskim ubogi rolnik (oracz książęcy - arator ducis) Piast z żoną Rzepką przygotowują się do uroczystości postrzyżynowej swojego jedynego syna i trzymają na tę okazję wieprzka oraz beczułkę piwa. Na książęcą ucztę do Gniezna przybywają dwaj tajemniczy wędrowcy, ale nie zostają przyjęci, lecz przeciwnie - odpędzeni spod bramy grodu; udają się więc na podgrodzie i trafiają do chaty Piasta, gdzie proszą o coś do jedzenia i picia. Gościnni gospodarze podają im wszystko, co przygotowali na postrzyżyny syna: pieczonego prosiaka i beczkę piwa. Goście jedzą i piją śmiało, bo wiedzą, że zjedzonego przez nich mięsa i wypitego piwa nie ubędzie, lecz przybędzie. Istotnie, rozmnożonym mięsem z prosiaka zapełniono dziesięć cebrów, a na piwo nie starczyło w domu naczyń i trzeba było szukać pustych dzbanów na 
uczcie u księcia, gdzie tymczasem napoju zabrakło. W końcu zaproszono księcia i jego współbiesiadników do chaty, a dwaj tajemniczy przybysze postrzygli syna Piasta i Rzepki, przejmując wobec dziecka rolę obrzędową należną ojcu i „na wróżbę przyszłych losów” nadali mu imię Siemowit. Etymologia tego imienia (siem - ród, rodzina i wit - pan, panowanie) zapowiadała, że chłopiec będzie założycielem rodu panującego. Rzeczywiście, gdy chłopiec wyrósł, Popiela i jego ród pozbawiono władzy, a Siemowit został księciem.

Tyle fabuła. Anonim-Gall obramował ją frazesami odwołującymi się do Opatrzności: że dwaj wędrowcy przybyli do Gniezna na książęcą ucztę „z tajemnej woli Boga”, że Bóg „nie waha się wynagradzać gościnności nawet u pogan” i że Siemowita, za powszechną zgodą, ustanowił księciem „król królów i książę książąt”, czyli sam Bóg. Frazesy te, trafnie określone przez Romana Michałowskiego jako „odautorskie komentarze” Galla, zaświadczały o pobożności kronikarza, ale nie miały związku $\mathrm{z}$ relacjonowaną przezeń fabułą mitu ${ }^{29}$. W losach Popiela łatwo zidentyfikować obecny m.in. w mitologii skandynawskiej motyw wędrowny ukaranej niegościnności wobec anonimowego przybysza, którym okazuje się przebrany Odyn lub Thor ${ }^{30}$.

Kim byli dwaj wędrowcy z piastowskiego mitu? Gall na ten temat milczy, ale $\mathrm{z}$ zapisanej przez niego fabuły jasno wynika, że dysponowali oni nadprzyrodzoną mocą rozmnażania jadła i napoju oraz darem proroczym. W dodatku wszystko czynili i mówili razem - jak bracia, a właściwie jak bliźniacy.

Pierwsze próby chrystianizacji tych postaci podjęto w późnym średniowieczu, gdy w XIV w. kronikarz Dzierzwa - zgodnie z wymogami teologicznej poprawności - powołując się na opinie krążące wśród duchowieństwa, postarał się przerobić tajemniczych gości Piasta na aniołów lub na świętych Jana i Pawła ${ }^{31}$. Gdyby jednak polskie duchowieństwo na początku XII w. uważało ich za obdarzonych mocą cudotwórczą aniołów lub świętych, Gall napisałby to z całą pewnością. Widocznie panowało w czasach Bolesława Krzywoustego przekonanie, że owi goście dysponujący nadprzyrodzoną mocą pomnażania jadła i napoju oraz przepowiadania przyszłości przybyli z pogańskiego Olimpu. Dlatego o ich tożsamości Gall wolał milczeć. Kim

29 R. Michałowski, Restauratio Poloniae w ideologii dynastycznej Anononima Galla, Przegl. Hist. 76 (1985), s. 461. Nie przekonuje mnie podjęta przez Czesława Deptułę (Galla Anonima mit genezy Polski, Lublin 2000, s. 268 n.), próba wpisania tych frazesów w fabularną strukturę mitu i oczyszczenia go w ten sposób z treści pogańskich.

30 Zob. J. Banaszkiewicz, Podanie o Piaście i Popielu. Studium porównawcze nad wczesnośredniowiecznymi tradycjami dynastycznymi, Warszawa 1986, s. 134-137.

31 Mierzwy kronika, [w:] MPH, t. 2, wyd. A. Bielowski, Lwów 1872, s. 185-187. 
byli ci dwaj w porządku mitologicznym? Narracja fabularna przypisuje im atrybuty wskazujące na słowiański odpowiednik wedyjskich Aświnów lub - jak kto woli rzymskich Dioskurów, czyli na boskie bliźnięta przynoszące ludziom obfitość. Nie znaczy to oczywiście, aby Gall wierzył w pogańskie bóstwa. Wierzył w Chrystusa, lecz wiedział, o czym pisze, a pisał dlatego, że ten pogański mit wciąż leżał u podstaw dynastycznej charyzmy Piastów.

Absolutnie kluczowe znaczenie ma w konstrukcji tego mitu informacja, że to nie Piast, lecz dwaj przybysze dokonali (razem!) magicznego obrzędu postrzyżyn i nadali Siemowitowi wyroczne imię wskazujące ex presagio futurorum, że będzie on założycielem dynastii. Aby rozszyfrować sens, jaki miało w obrzędowej wyobraźni europejskich barbarzyńców nadanie imienia (a właściwie nazwy osobowej) przez istotę nadprzyrodzoną, warto sięgnąć do spisanego u schyłku VII w. z ustnej tradycji tekstu pod nazwą Origo gentis Langobardorum. Prócz inwokacji in nomine Domini amen nie ma w tym tekście nic chrześcijańskiego, fabuła zaś przedstawia się następująco: na wyspie Skandanan lud Winilów, któremu przewodzili bracia Ibor i Agio ze swą matką Gambarą, szykował się do bitwy z Wandalami, którym przewodzili Ambri i Assi. Przed bitwą wodzowie Wandalów zwrócili się do Wotana, prosząc o zwycięstwo, Wotan zaś odpowiedział im, że da zwycięstwo tym, których o świcie pierwszych ujrzy na polu bitwy. Ze swej strony Gambara ze swymi synami poprosiła Freję, małżonkę Wotana, o pomoc dla Winilów, Freja zaś poradziła im, by o świcie wyszli na pole bitwy razem ze swymi żonami, które powinny rozpuścić włosy i ułożyć je wokół twarzy na podobieństwo bród. Następnie o świcie Freja obróciła łóżko swego męża Wotana ku wschodowi i zbudziła go, a Wotan, ujrzawszy kobiety Winilów z włosami ułożonymi wokół twarzy, zakrzyknął: „kim są ci długobrodzi?” (qui sunt isti longibarbae?). Na to Freja odpowiedziała: skoro dałeś im imię, daj im też zwycięstwo (sicut dedisti eis nomen, da eis et victoriam). Wotan uległ podstępowi Frei i dał im zwycięstwo, a nawet postanowił, by odtąd już zawsze zwyciężali swoich wrogów. „Odtąd Winilowie nazywają się Longobardami”32.

Zgodnie z przenikliwą analizą Stefana Gasparriego, nadając Winilom nowe imię, Wotan wystąpił wobec nich w ojcowskiej roli, a tym samym adoptował ich; w dodatku ich nowa nazwa (imię, nomen, Name) była w germańskiej mitologii jednym z przydomków samego Wotana („Długobrody”). W VIII w. Paweł Diakon szczegółowo opisał polichromie wymalowane w kaplicy pałacowej królów longobardzkich

32 Krytyczna edycja: Annalisa Bracciotti, Origo gentis Langobardorum, Roma 1998, s. 105-107 . 
w Monzy na rozkaz królowej Teodolindy (589-628). Longobardowie mieli na tych freskach podgolone karki, na ciemieniu zaś długie włosy rozczesane na dwie strony i okalające twarze w taki sposób, aby łączyły się z brodą. Była to oczywiście czytelna aluzja do mitu o winilskich kobietach z włosami ułożonymi wokól twarzy na podobieństwo bród, lecz freski z Monzy zawierały również inną istotną treść ideową. Barbarzyńcy germańscy traktowali adopcję jako zabieg magiczny ustanawiający faktyczne pokrewieństwo, przeto adoptowane dzieci powinny były być fizycznie podobne do przybranego ojca ${ }^{33}$. Przekonanie to nie było obce także myśleniu mitycznemu słowiańskich barbarzyńców. Według Saksa Gramatyka najwyższy kapłan w Arkonie wyróżniał się długą brodą i włosami, podczas gdy Świętowit przedstawiony został na posągu z włosami i brodą tak przystrzyżonymi, jakby rzeźbiarz chciał oddać „fryzurę u Rugian zwyczajną"34. Podobnie jak na malowidłach w Monzy, ogół współplemieńców miał strzyc się i czesać tak, by upodobnić się fizycznie do boskiego praojca ludu. Nie wiemy, czy Świętowit był naturalnym, czy adopcyjnym przodkiem Rugian, chyba jednak nie ma to znaczenia.

Czesław Deptuła i Jacek Banaszkiewicz - w tym wypadku zgodnie, choć niezależnie jeden od drugiego - interpretowali zniknięcie piwa na uczcie u Popiela i rozmnożenie piwa w chacie Piasta jako przeniesienie z jednego na drugiego nadprzyrodzonych mocy „króla-żywiciela”35. Ten efektowny i przenikliwy pomysł wymaga moim zdaniem uściślenia. Po pierwsze - o czym obaj autorzy wiedzieli i pisali - Piast nie był królem. Księciem został dopiero jego syn Siemowit. Po drugie - i to wydaje się najważniejsze - sprawcą rozmnożenia napoju w chacie oracza i znikania napoju na dworze Popiela nie był Piast, lecz dwaj tajemniczy wędrowcy. Wiedzieli oni z góry, że piwa, które piją w tej chacie, nie ubędzie, lecz przybędzie, podczas gdy Piast i Rzepka byli tym zaskoczeni, a gdy wpadli na pomysł, by w tej sytuacji zaprosić do siebie księcia z jego biesiadnikami, nie śmieli tego uczynić, nie zapytawszy najpierw wędrowców. Nie Piast zatem, lecz dwaj wędrowcy dysponowali nadprzyrodzoną mocą żywicielską, która pozwalała rozmnażać piwo i mięso. Możemy, a nawet musimy

33 Paolo Diacono, Storia dei Longobardi, wyd. L. Capo, Verona 1995, s. 200; S. Gasparri, La cultura tradizionale dei Longobardi. Strutture tribali e resistenze pagane, Spoleto 1983, s. 55-61; K. Modzelewski, Barbarzyńska Europa, Warszawa 2004, s. 59-64.

34 Saxo, XIV, 39, 2: Corrasae barbae, crines attonsi figurabantur, ut artificis industriam Rugianorum ritum in cultu capitum putares.

35 C. Deptuła, Problem mitu monarchy - dawcy żywności w Polsce średniowiecznej na przykładzie podania o Piaście, Zeszyty naukowe KUL 18 (1975), nr 3, s. 41-55; J. Banaszkiewicz, Podanie o Piaście i Popielu, s. 135-155. 
uznać tych dwóch za słowiańską odmianę Dioskurów, gdyż tylko taka wykładnia daje się uzgodnić z fabularną strukturą mitu ${ }^{36}$.

Tym sposobem znaleźliśmy się w sytuacji paradoksalnej: wykładnia najstarszego zapisu piastowskiego mitu dynastycznego nie została uwzględniona w argumentacji Gieysztora, lecz - dzięki ulubionej przez pozytywistów filologicznej analizie źródła pisanego - wzmacnia jego rozumowanie oparte na komparatystycznej przesłance. $\mathrm{W}$ naszych czasach strukturalizm wychodzi już z mody, ale z tej próby wychodzi obronną ręką.

Nadesłany: 15 II 2019

Po korektach redakcyjno-recenzyjnych: 6 VI 2021

Zaakceptowany: 6 VI 2021

Profesor Karol Modzelewski zmarł 28 IV 2019 r. W tekście uwzględniono minimalne poprawki redakcyjne i uwagi recenzentów, których Autor nie mógł już zatwierdzić.

\section{Résumé}

\section{Antipositivist Breakthrough and Structuralism in Aleksander Gieysztor's Mitologia Stowian [Mythology of the Slavs]}

This paper consists of two parts. The first presents and analyses the research method used by Aleksander Gieysztor to reconstruct the pre-Christian beliefs and mythology of the early medieval Slavs. Gieysztor was inspired by Georges Dumézil's works devoted to comparative research into the beliefs and rituals of Indo-European peoples, in particular the Indo-Iranians, Romans and Germans. The use of the comparative method as well as ethnographic and folkloristic sources, hitherto absent in positivist historiography, and even excluded by it as a research method, was Aleksander Gieysztor's original contribution into this research and a consequence of Gieysztor adopting the research questionnaire and the conceptual apparatus developed by the French humanities from the circle of the Parisian 'Annales' School, in particular the methodology of Claude Lévi-Strauss's structural anthropology and the concept of longue durée. Their employment allowed Gieysztor to make an 'antipositivist breakthrough' in historiography dealing with the ancient Slavic religion. For example, Gieysztor reconstructed the pre-Christian Slavic pantheon. In the second part of the article, the author, referring to the

36 Do podobnego wniosku skłaniał się już w 1986 r. J. Banaszkiewicz (Podanie o Piaście i Popielu, s. 143), przyjmując, że Siemowita postrzygli i nadali mu imię „dwaj goście-bogowie”, ale zawahał się i w końcu uznał ich po chrześcijańsku za „dwóch bożych wysłanników” (tamże, s. 149). 
method proposed by Gieysztor, reinterprets the dynastic myth of the Piast dynasty contained in the first chronicle of the princes of Poland (before 1116). In Modzelewski's opinion, the account of the founding of the Polish ruling family, written down by Gallus Anonymous, a Christian monk and chronicler, a century and a half after the Piasts had been baptised, is rooted in the pre-Christian Slavonic religion. The first Piast duke, Siemowit, was adopted by two Slavic gods-the dioskuri during the ceremonial hair-cutting and destined to become a duke and start a dynasty. The author thus proves that in the pre-Christianisation era, the Polish princely dynasty was regarded by its subjects as descending from the original Slavic gods, a phenomenon observed in relation to the royal families of Germanic peoples.

Translated by Agnieszka Tokarczuk

\section{Bibliografia/Bibliography}

Anonim tzw. Gall, Anonima tzw. Galla Kronika, czyli dzieje książąt i władców polskich, wyd. K. Maleczyński, Monumenta Poloniae Historica, seria II, t. 2 Kraków 1952 Anonim tzw. Gall, Kronika Polska, tłum. R. Grodecki, Biblioteka Narodowa, seria I, nr 59, Kraków 1923

Aymard M., La longue durée aujourd'hui: bilan d'un demi-siècle (1958-2008), [w: ] From Florence to Mediterranean and Beyond: Essays in Honour of Anthony Molho, red. A. Molho i in., Firenze 2009, t. 2, s. 559-579

Banaszkiewicz J., Pan Rugii - Rugiewit i jego towarzysze z Gardźca - Porewit i Porenut. Sakso Gramatyk, Gesta Danorum, XIV, 39, 38-41, [w:] Stowiańszczyzna w Europie, wyd. Z. Kurnatowska, Wrocław 1996, t. I, s. 75-82

Banaszkiewicz J., Podanie o Piaście i Popielu. Studium porównawcze nad wczesnośredniowiecznymi tradycjami dynastycznymi, Warszawa 1986

Braudel F., Histoire et sciences sociales. La longue durée, Annales ESC 13 (1968), nr 4, s. $725-753$

Braudel F., La Méditerranée et le monde méditerranéen à l'époque de Philippe II, Paris 1949

Braudel F., Morze Śródziemne i świat śródziemnomorski w epoce Filipa II, z jęz. francuskiego przeł. T. Mrówczyński i M. Ochab, t. 1-2, Gdańsk 1976

Deptuła C., Galla Anonima mit genezy Polski, Lublin 2000

Deptuła C., Problem mitu monarchy - dawcy żywności w Polsce średniowiecznej na przykładzie podania o Piaście, Zeszyty naukowe KUL 18 (1975), nr 3, s. 41-55

Dumézil G., Bogowie Germanów: szkice o ksztattowaniu się religii skandynawskiej, przeł. A. Gronowska, Warszawa 2006 
Gasparri S., La cultura tradizionale dei Longobardi. Strutture tribali e resistenze pagane, Spoleto 1983, s. 55-61

Geremek B., Geschichte der Armut: Elend und Barmherzigkeit in Europa, aus dem Polnischen von F. Griese, München-Zürich 1988

Geremek B., La piedad y la horca. Historia de la miseria y de la caridad en Europa, trad. J.A. Matesanz, Madrid 1989

Geremek B., La pietà e la forca: storia della miseria e della carità in Europa, trad. A. Marx Vannini con la collab. di M. Frau e B. Verdiani, Roma - Bari 1986

Geremek B., La potence ou la pitié: l'Europe et les pauvres, du Moyen âge à nos jours, trad. J. Arnold-Moricet, Paris 1987

Geremek B., Litość i szubienica: dzieje nędzy i miłosierdzia, Warszawa 1989

Gieysztor A., Mitologia Stowian, wyd. 1, Warszawa 1982

Gieysztor A., Mitologia Stowian, wyd. 3, rozszerzone i zmienione, wstęp K. Modzelewski; posłowie L.P. Słupecki; oprac. na podst. rękopisu A. Pieniądz, Warszawa 2006

Kula W., An economic theory of the feudal system: towards a model of the Polish economy 1500-1800, transl. by L. Garner, London 1976

Kula W., Le misure e gli uomini dall'antichità a oggi, trad. A. Vivanti Salmon, Roma-Bari 1987

Kula W., Les mesures et les hommes, trad. J. Ritt; texte révu et établi par K. Pomian et J. Revel, Paris 1984

Kula W., Measures and men, transl. by R. Szreter, Princeton 1986

Kula W., Miary i ludzie, Warszawa 1970

Kula W., Problemi e metodi di storia economica, trad. A. Zieliński, Milano 1972

Kula W., Problemy i metody historii gospodarczej, Warszawa 1963

Kula W., Teoria econòmica del sistema feudal, trad. di G. Calaforra, València 2009

Kula W., Teoria economica del sistema feudale: proposta di un modello, trad. B. Bravo e K. Żaboklicki, Torino 1970

Kula W., Teoria ekonomiczna ustroju feudalnego: próba modelu, Warszawa 1962

Kula W., Théorie économique du système féodal: pour un modèle de l'économie polonaise $16^{e}-18^{e}$ siècles, trad. du polonais; édition revue et augmentée, préface de F. Braudel, Paris-La Haye 1970

Kula W., The problems and methods of economic history, transl. by R. Szreter; edited, with an introduction by S. Szreter, Aldershot 2001

Lévi-Strauss C., Anthropologie structurale, Paris 1958

Lévi-Strauss C., Antropologia strukturalna, wstępem poprzedził B. Suchodolski, 
przeł. oraz Słownik pojęć antropologii strukturalnej, oprac. K. Pomian, wyd. 1, Warszawa 1970

Lévi-Strauss C., Le dédoublement de la représentation dans les arts de l'Asie et de l'Amérique, Renaissance. Revue trimestrielle publiée par l'École Libre des Hautes Études de New York 2-3 (1944-1945), s. 168-186

Łowmiański H., Studia nad dziejami Stowiańszczyzny, Polski i Rusi w wiekach średnich, Poznań 1986

Łowmiański H., Studia nad dziejami Wielkiego Księstwa Litewskiego, Poznań 1983

Łowmiański H., Studia nad początkami społeczeństwa i państwa litewskiego, t. 1-2, Wilno 1931-1932

Malicki K., Chrzest Rugii 1168 r. Model chrystianizacji - praca magisterska pod kierunkiem prof. J. Banaszkiewicza, Warszawa 2000 (maszynopis w archiwum Dziekanatu Wydziału Historii Uniwersytetu Warszawskiego)

Michałowski R., Restauratio Poloniae w ideologii dynastycznej Anononima Galla, Przegląd Historyczny 76 (1985), nr 3, s. 457-480

Mierzwy kronika, [w:] Monumenta Poloniae Historica, t. II, wyd. A. Bielowski, Lwów 1872, s. 163-190

Modzelewski K., Barbarzyńska Europa, Warszawa 2004

O'Brien S., Dioscuric Elements in Celtic and Germanic Mythologies, The Journal of Indo-European Studies 10 (1982), s. 117-136

Origo gentis Langobardorum, wyd. A. Bracciotti, Roma 1998

Paolo Diacono, Storia dei Longobardi, wyd. L. Capo, Verona 1995

Pomian K., Porządek czasu, z jęz. francuskiego przeł. T. Stróżyński, Gdańsk 2014

Publius Cornelius Tacitus, Germania, [w:] Publius Cornelius Tacitus, Agricola; Germania; Dialogus, The Loeb Classical Library. Tacitus, t. 1, Cambridge, Mass.-London 1996

Saxonis Grammatici Gesta Danorum, wyd. J. Olrik, H. Raedr, t. I, Hauniae 1937

Tacyt, Germania, [w:] Tacyt, Dzieła, t. 2, tłum. Seweryn Hammer, Warszawa 1957 Třeštík D., Mýty kmene Čechů (7.-10. století), Praha 2003

Tymieniecki K., Początki społeczeństwa i państwa litewskiego, Roczniki Dziejów społecznych i gospodarczych 2 (1932-1933), s. 145-162

Tymieniecki K., Prawo niemieckie w rozwoju społecznym wsi polskiej, Kwartalnik Historyczny 37 (1923), s. 38-78

Tymieniecki K., Procesy twórcze formowania się społeczeństwa polskiego w wiekach średnich, Warszawa 1921 
Tymieniecki K., Sądownictwo w sprawach kmiecych a ustalanie się stanów na Mazowszu pod koniec wieków średnich, Poznań 1922

Tymieniecki K., Wolność kmieca na Mazowszu w XV w., Poznań 1921

Tymowski M., Państwa Afryki przedkolonialnej, Wrocław 1999

Tymowski M., The origins and structures of political institutions in pre-colonial Black Africa: dynastic monarchy, taxes and tributes, war and slavery, kinship and territory, with a foreword by H.J.M. Claessen, Lewistone 2009 